\section{Nitrogen Fertilization in Soil Affects Physiological Characteristics and Quality of Green Tea Leaves}

\author{
Fang Xiao, Zaiqiang Yang ${ }^{1}$, and Haijing Huang \\ Collaborative Innovation Center on Forecast and Evaluation of Meteorological \\ Disasters, Nanjing University of Information Science \& Technology, Nanjing \\ 210044, China
}

\section{Fei Yang}

College of Languages and Cultures, Nanjing University of Information

Science \& Technology, Nanjing, 210044, China

\section{Liyun Zhu and Dong Han \\ Collaborative Innovation Center on Forecast and Evaluation of Meteorological Disasters, Nanjing University of Information Science \& Technology, Nanjing 210044, China}

\section{Additional index words. hormone nitrogen, photosynthetic characteristics, quality, tea tree}

\begin{abstract}
To study the effects of soil nitrogen (N) fertilization on tea growth, quality and yield, a controlled experiment with green tea [Camellia sinensis (L.) O. Ktze] was conducted. Five $\mathbf{N}$ fertilization treatments in soil were designed: $0,0.97,1.94,3.88$, and $5.82 \mathrm{~g} / \mathrm{kg} /$ pot, which were subsequently recorded as $\mathrm{N} 0, \mathrm{~N} 1, \mathrm{~N} 2, \mathrm{~N} 3$, and $\mathrm{N} 4$. The changes to young shoot biomass, total $N$ and carbon (C), Soil and Plant Analyzer Development (SPAD) value, photosynthetic parameters, senescent characteristics, endogenous hormones, and the quality of green tea leaves were investigated. The results showed that with the increase in $\mathbf{N}$ fertilization level, the young shoot biomass, total $\mathbf{N}$ and $\mathbf{C}$, SPAD value, net photosynthetic rate $\left(P_{\mathrm{N})}\right.$, transpiration rate $\left(T_{\mathrm{r}}\right)$, stomatal conductance $\left(g_{\mathrm{S}}\right)$, superoxide dismutase activity, indoleacetic acid, gibberellin, zeatin (ZT), caffeine, and amino acids increased at first and then decreased, the maximums appeared at $3.88 \mathrm{~g} / \mathrm{kg}$ / pot; whereas the intercellular $\mathrm{CO}_{2}$ concentration $\left(C_{\mathrm{i}}\right)$, malondialdehvde contents, abscisic acid (ABA), polyphenol contents, and the ratio of polyphenols (PP) to free amino acid decreased at first and then increased, the minimums appeared at $3.88 \mathrm{~g} / \mathrm{kg} /$ pot. The immediately significant change in all parameters appeared after 1 month of $\mathbf{N}$ treatments. The experiment showed that $3.88 \mathrm{~g} / \mathrm{kg} /$ pot $\mathrm{N}$ fertilization level was the best for growth, quality, and yield of tea, which could provide a theoretical basis for shortterm $\mathrm{N}$ fertilization management in tea tree.
\end{abstract}

Tea [C. sinensis (L.) O. Ktze] is a kind of traditional economic crop in southern China, and tea industry can quickly promote the local economy development (Zhang et al., 2010). Fertilization is an effective way to supply nutrients for tea tree, and it is also an important factor to improve yield and quality of tea (Ruan et al., 2001).

Nitrogen, either from organic or mineral fertilization, plays an important role in the growth and development of tea tree. Meanwhile, it is an important component of chlorophyll, protein, vitamins, enzymes, alkaloids, amino acids, and hormones in tea leaves, and it can significantly affect the yield and quality of tea leaves (Bethke et al., 2007; Kumar et al., 2004; Zhou et al., 2006). Previous studies have investigated

Received for publication 23 Jan. 2018. Accepted for publication 19 Mar. 2018.

Funding for this study was provided by the Special Scientific Research (GYHY201306037).

${ }^{1}$ Corresponding author. E-mail: yzq6751@163. com. focused on the effects of $\mathrm{N}$ fertilization level on tea yield and quality, whereas the effects of $\mathrm{N}$ fertilization level on photosynthetic characteristics, senescent characteristics, and endogenous hormones of spring tea have not been reported. In this article, we studied the effects of different $\mathrm{N}$ fertilization levels on photosynthetic parameters, chlorophyll content, antioxidant enzyme activity, endogenous hormones, and quality of tea leaves. The aim was to provide a theoretical basis for reasonably using $\mathrm{N}$ fertilization and improving yield and quality of tea leaves.

\section{Materials and Methods}

Plant materials and treatments. The experiment was conducted on 15 Jan. 2014 at Nanjing University of Information Science and Technology, China (lat. $32^{\circ} 2^{\prime} \mathrm{N}$, long. $118^{\circ} 7^{\prime} \mathrm{E}$, and altitude $22 \mathrm{~m}$ ). Three 2-yearold rooted cuttings (cultivar Wuniuzao, plant height $30 \pm 1 \mathrm{~cm}$ ) were transferred to each pot $(39 \mathrm{~cm} \times 36 \mathrm{~cm}$, height $\times$ diameter) filled with $8 \mathrm{~kg}$ air-dried soil that passed through a $5-\mathrm{mm}$ sieve. The physicochemical properties of the growing media were determined by Hanlon (1994): organic matter $17.6 \mathrm{~g} \cdot \mathrm{kg}^{-1}$, total $\mathrm{N}$ $0.78 \mathrm{~g} \cdot \mathrm{kg}^{-1}$, available $\mathrm{N} 21.57 \mathrm{mg} \cdot \mathrm{kg}^{-1}$, available phosphorus $37.21 \mathrm{mg} \cdot \mathrm{kg}^{-1}$, available potassium $80.34 \mathrm{mg} \cdot \mathrm{kg}^{-1}$, and $\mathrm{pH} 5.7$.

Five $\mathrm{N}$ fertilization levels were established at urea concentrations of $0,0.44$, $0.88,1.76$, and $2.64 \mathrm{~g} / \mathrm{kg} /$ pot, which is equivalent to $0,0.97,1.94,3.88$, and $5.82 \mathrm{~g} / \mathrm{kg} /$ pot $\mathrm{N}$ fertilization levels, respectively; these levels are subsequently recorded as N0, N1, N2, N3, and N4 according to Ruan et al. (2001). Each treatment had 15 pots. The fertilization was dissolved in water and applied to each treatment on 15 Feb. 2014. Plants were placed in the greenhouse at $28 / 18{ }^{\circ} \mathrm{C}$ day/night air temperature with natural light. The relative humidity ranged from $60 \%$ to $70 \%$. The plants were watered as needed.

Collection of samples for chemical analyses. Samples of young shoots (plant height $40-50 \mathrm{~cm}$ and crown diameter $30-40 \mathrm{~cm}$ ) consisting of one bud with two leaves were collected and frozen quickly in liquid $\mathrm{N}$, and the samples were stored at $-20{ }^{\circ} \mathrm{C}$ until freeze-dried. Collection of the young shoot samples began at the $\mathrm{N}$ supplements ( $15 \mathrm{Feb}$.) and continued at intervals of 15 Mar., 1 Apr., 16 Apr., and 1 May 2014.

Chlorophyll measurements. The relative content of chlorophyll in tea leaves was measured by the SPAD chlorophyll meter. The first mature and undamaged leave was randomly taken from tea trees in each treatment, and the SPAD was read with SPAD502 (Minolta Co., Ltd., Osaka, Japan) (Yang et al., 2008). Three replications were measured for each leaf and 20 leaves for each treatment.

Photosynthetic parameters measurements. The fifth to eighth functional leaves from the top of plants were selected, and $P_{\mathrm{N}}, g_{\mathrm{S}}, C_{\mathrm{i}}, T_{\mathrm{r}}$ were measured between 09:00 and 11:00 AM 
Table 1. Effects of nitrogen fertilization treatments on young shoot biomass (g DW/plant) of green tea on different dates.

\begin{tabular}{|c|c|c|c|c|c|}
\hline \multirow[b]{2}{*}{ Treatments } & \multicolumn{5}{|c|}{ Date } \\
\hline & $2 / 15$ & $3 / 15$ & $4 / 1$ & $4 / 16$ & $5 / 1$ \\
\hline N1 & $0.33 \pm 0.02 \mathrm{Ea}$ & $0.49 \pm 0.03 \mathrm{Dcd}$ & $0.62 \pm 0.04 \mathrm{Cc}$ & $0.89 \pm 0.05 \mathrm{Bcd}$ & $1.14 \pm 0.06 \mathrm{Ac}$ \\
\hline N3 & $0.32 \pm 0.02 \mathrm{Ea}$ & $0.68 \pm 0.04 \mathrm{Da}$ & $0.89 \pm 0.05 \mathrm{Ca}$ & $1.22 \pm 0.07 \mathrm{Ba}$ & $1.73 \pm 0.08 \mathrm{Aa}$ \\
\hline N4 & $0.35 \pm 0.02 \mathrm{Ea}$ & $0.62 \pm 0.0 .3 \mathrm{Dab}$ & $0.76 \pm 0.05 \mathrm{Cb}$ & $1.08 \pm 0.05 \mathrm{Bb}$ & $1.35 \pm 0.05 \mathrm{Ab}$ \\
\hline
\end{tabular}

Results are presented as mean $\pm \mathrm{SD}(n=3)$. Uppercase and lowercase letters indicate significance of $P<0.05$ by Duncan's test within each row and column, respectively. $\mathrm{N} 0, \mathrm{~N} 1, \mathrm{~N} 2, \mathrm{~N} 3$, and $\mathrm{N} 4$ refer to $0,0.97,1.94,3.88$, and $5.82 \mathrm{~g} / \mathrm{kg} / \mathrm{pot} \mathrm{N}$ fertilization, respectively.

Table 2. Effects of nitrogen fertilization treatments on total $\mathrm{N}$ contents $\left(\mathrm{mg} \cdot \mathrm{g}^{-1}\right)$ of green tea on different dates.

\begin{tabular}{|c|c|c|c|c|c|}
\hline \multirow[b]{2}{*}{ Treatments } & \multicolumn{5}{|c|}{ Date } \\
\hline & $2 / 15$ & $3 / 15$ & $4 / 1$ & $4 / 16$ & $5 / 1$ \\
\hline N1 & $8.1 \pm 0.67 \mathrm{Eab}$ & $13.5 \pm 0.85 \mathrm{Dc}$ & $19.8 \pm 1.02 \mathrm{Cd}$ & $27.6 \pm 1.09 \mathrm{Bd}$ & $31.7 \pm 1.10 \mathrm{Ad}$ \\
\hline $\mathrm{N} 4$ & $8.8 \pm 0.59 \mathrm{Eab}$ & $20.6 \pm 0.93 \mathrm{Db}$ & $34.5 \pm 0.99 \mathrm{Cb}$ & $42.7 \pm 1.31 \mathrm{Bb}$ & $46.9 \pm 1.28 \mathrm{Ab}$ \\
\hline
\end{tabular}
respectively. N0, N1, N2, N3, and N4 refer to $0,0.97,1.94,3.88$, and $5.82 \mathrm{~g} / \mathrm{kg} /$ pot N fertilization, respectively.

Table 3. Effects of nitrogen fertilization treatments on total $\mathrm{C}$ contents $\left(\mathrm{mg} \cdot \mathrm{g}^{-1}\right)$ of green tea in different dates.

\begin{tabular}{|c|c|c|c|c|c|}
\hline \multirow[b]{2}{*}{ Treatments } & \multicolumn{5}{|c|}{ Date } \\
\hline & $2 / 15$ & $3 / 15$ & $4 / 1$ & $4 / 16$ & $5 / 1$ \\
\hline N1 & $432.5 \pm 4.87 \mathrm{Ca}$ & $451.4 \pm 4.94 \mathrm{Bbc}$ & $472.4 \pm 6.21 \mathrm{Bc}$ & $482.5 \pm 5.75 \mathrm{Abc}$ & $490.6 \pm 5.69 \mathrm{Abc}$ \\
\hline N4 & $442.8 \pm 5.08 \mathrm{Da}$ & $452.9 \pm 4.90 \mathrm{Cab}$ & $476.8 \pm 5.83 \mathrm{Bab}$ & $480.8 \pm 5.47 \mathrm{Aab}$ & $488.4 \pm 5.96 \mathrm{Aab}$ \\
\hline
\end{tabular}
respectively. N0, N1, N2, N3, and $\mathrm{N} 4$ referred to $0,0.97,1.94,3.88$, and $5.82 \mathrm{~g} / \mathrm{kg} / \mathrm{pot} \mathrm{N}$ fertilization, respectively.

using a portable photosynthesis measurement system (LI-6400; LI-COR Bioscience, Lincoln, $\mathrm{NE})$. For each measurement, the leaf was exposed to $1000 \mu \mathrm{mol}$ (photon) $\cdot \mathrm{m}^{-2} \cdot \mathrm{s}^{-1}$ photosynthetic photon flux density, the temperature in the leaf chamber was set to $25^{\circ} \mathrm{C}$, the $\mathrm{CO}_{2}$ concentration was $380 \pm 10 \mu \mathrm{mol}\left(\mathrm{CO}_{2}\right)$. $\mathrm{mol}^{-1}$, and relative humidity was $60 \%$ to $70 \%$.

Antioxidant enzyme measurements. The same functional leaves as those used in the photosynthesis measurements were sampled and immediately frozen in liquid $\mathrm{N}$ and stored at $-40{ }^{\circ} \mathrm{C}$ for further enzyme analyses. Superoxide dismutase (SOD) (EC 1.15.1.1) activity was measured with extracts obtained from $300 \mathrm{mg}$ frozen leaf tissue followed by Beauchamp and Fridovich (1973). The frozen leaves were homogenized in an extraction buffer containing $50 \mathrm{~mm}$ phosphate buffer ( $\mathrm{pH} 7.8), 0.1 \%(\mathrm{w} / \mathrm{v})$ ascorbate, and $0.05 \%$ (w/v) $\beta$-mercaptoethanol. The $3-\mathrm{mL}$ assay mixture contained $50 \mathrm{~mm}$ phosphate buffer ( $\mathrm{pH}$ 7.8), $9.9 \mathrm{~mm} \cdot \mathrm{L}^{-1}$ methionine, $0.025 \%(\mathrm{w} / \mathrm{v})$ nitroblue tetrazolium chloride (NBT), and $0.0044 \%(\mathrm{w} / \mathrm{v})$ riboflavin. SOD activity was measured using the fact that the enzyme inhibits the photoreduction of NBT.

Lipid peroxidation measurements. Lipid peroxidation was estimated in terms of malondialdehyde (MDA) content. The MDA content was determined according to Zhao et al. (1994). Fresh leaves (1.0 g) were ground in $10 \%$ trichloroacetic acid and then centrifuged at $3000 \mathrm{rpm}$ for $10 \mathrm{~min}$. Two milliliters of the supernatant was mixed with $2 \mathrm{~mL}$ of $0.6 \%$ thiobarbituric acid (TBA) and incubated

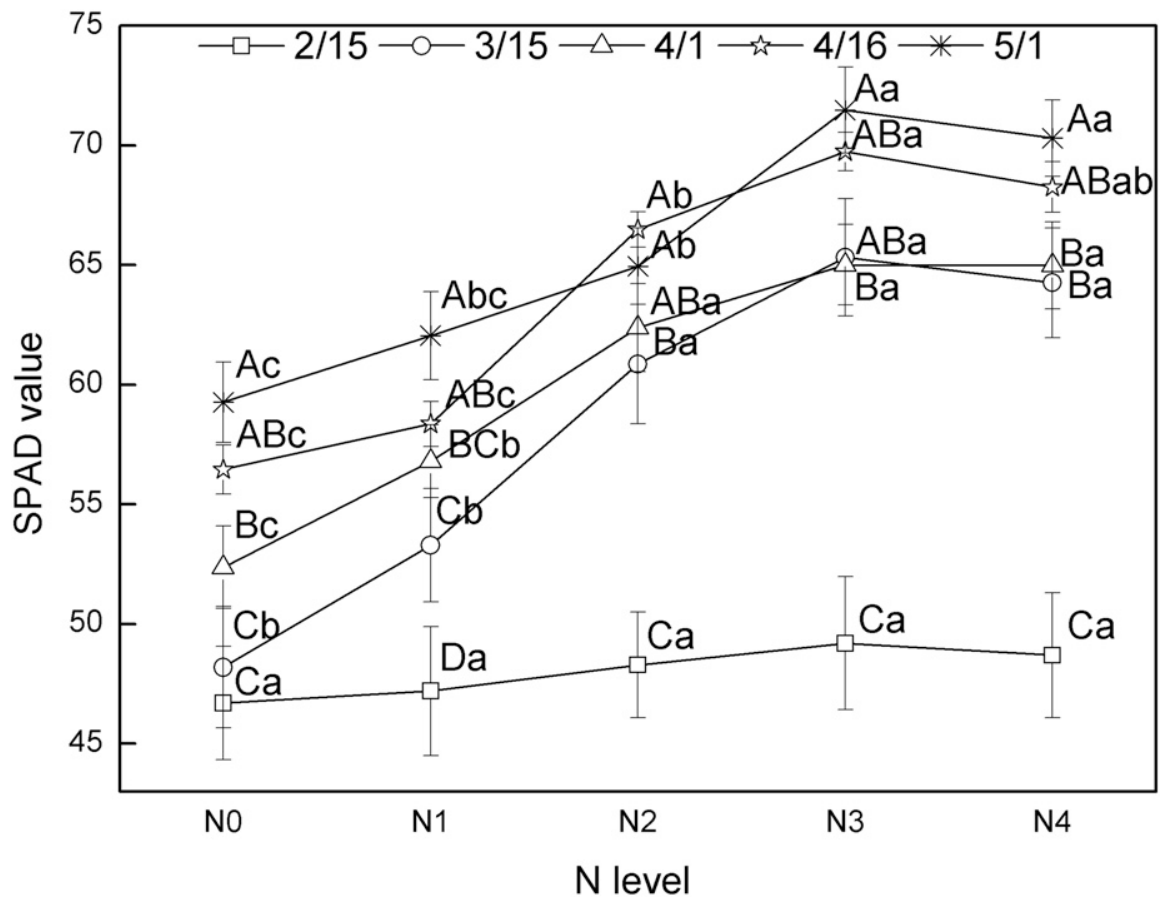

Fig. 1. Changes in leaf chlorophyll content (Soil and Plant Analyzer Development) in 'Wuniuzao' after N fertilization. Uppercase and lowercase letters indicate significance of $P<0.05$ by Duncan's test under the same $\mathrm{N}$ level and date, respectively. Error bars represent sD, $n=3 . \mathrm{N} 0, \mathrm{~N} 1, \mathrm{~N} 2, \mathrm{~N} 3$, and $\mathrm{N} 4$ refer to $0,0.97,1.94,3.88$, and $5.82 \mathrm{~g} / \mathrm{kg} /$ pot N fertilization, respectively. IAA $=$ indole-3-acetic acid; $\mathrm{GA}_{3}=$ gibberellin $\mathrm{A}_{3} ; \mathrm{ZT}=$ zeatin, and $\mathrm{ABA}=$ abscisic acid.

for $30 \mathrm{~min}$ at $100{ }^{\circ} \mathrm{C}$ to form an MDA-TBA2 adduct. The mixture was cooled rapidly in an ice bath. After centrifugation at $5000 \mathrm{rpm}$ for
$10 \mathrm{~min}$, the absorbance was measured at 450 $\mathrm{nm}, 532 \mathrm{~nm}$, and $600 \mathrm{~nm}$. Lipid peroxidation was expressed as $\mu \mathrm{mol} \cdot \mathrm{g}^{-1}$ (FM) using the 
following formula: MDA $\left[\mu \mathrm{mol} \cdot \mathrm{g}^{-1}(\mathrm{FM})\right]=$ $6.45\left(A_{532}-A_{600}\right)-0.56 A_{450}$, where $A_{532}, A_{600}$, and $A_{450}$ are absorbance measured at 532,600, and $450 \mathrm{~nm}$, respectively.

Endogenous hormones measurements. The youngest leaf buds consisting of one bud with two leaves were collected, immediately frozen in liquid $\mathrm{N}$, and then stored in a low-temperature freezer $\left(-40{ }^{\circ} \mathrm{C}\right)$. The frozen samples were used for analyses of indole-3-acetic acid (IAA), gibberellin $\mathrm{A}_{3}$ $\left(\mathrm{GA}_{3}\right), \mathrm{ZT}$, and ABA contents with a highperformance liquid chromatography (Agilent 1200 series HPLC-ultraviolet) according to Pan and Qian (2006). Finely milled samples were extracted in $10 \mathrm{~mL}$ cold methanol $(80 \%)$ overnight. After the samples had been filtered, the residue was extracted twice in $10 \mathrm{~mL}$ cold methanol $(80 \%)$ and combined with the supernatant. The samples were then extracted and bleached with an equal volume of light petroleum. The ether phase was discarded and the water phase was retained. This process was repeated three times. The samples were then vacuumed and evaporated to $1 / 4$ of their original volume at $37{ }^{\circ} \mathrm{C}$. The $\mathrm{pH}$ of the solution was adjusted to 2.8 and the required sample was extracted with an equal volume of acetic ether. The water phase was discarded and the ester phase was extracted three times. The samples were then vacuumed and evaporated to $1 \mathrm{~mL}$ at $37{ }^{\circ} \mathrm{C}, 2 \mathrm{~mL}$ of methanol was added, and then the samples were measured by LC 600 chromatography workstation (LC 600 supporting software) over a $0.45-\mu \mathrm{m}$ microporous filter membrane. A chromatographic column [Agilent 5 HC-C18 $(150 \mathrm{~mm} \times$ $4.6 \mathrm{~mm}, 5 \mu \mathrm{m})$ ] was used to separate the compounds. The mobile phase was methanol$0.075 \%$ glacial acetic acid aqueous solution (45:55), the flow velocity was $0.7 \mathrm{~mL} \cdot \mathrm{min}^{-1}$, the column temperature was $35^{\circ} \mathrm{C}$, the sample volume was $20 \mu \mathrm{L}$, and the detection wavelength was $210 \mathrm{~nm}$.

Elemental concentrations and inherent quality determination. Finely milled, dried plant samples of $0.5 \mathrm{~g}$ from each treatment were used for analysis of total $\mathrm{N}$ and $\mathrm{C}$ with an elemental analyser (Carlo Erba, Milano, Italy). Polyphenols and caffeine were extracted twice with $70 \%$ aqueous methanol (v/v) at $70{ }^{\circ} \mathrm{C}$ for $10 \mathrm{~min}$ at a ratio of $1: 25(\mathrm{w} / \mathrm{v})$. The concentration of total PP was measured with the Folin-Ciocalteu method (Astill et al., 2001). Caffeine was analyzed by HPLC on a column packed with ODS-5 ST ( $5 \mu \mathrm{m}$, $150 \times 4.6 \mathrm{~mm}$; Grom, Rottenburg-Hailfingen, Germany) (Yang, 2011). The elution solutions and gradients were essentially the same as previously described. Standards of caffeine was purchased from Sigma.
After the measurement of PP and caffeine, free amino acids were extracted with chloroform:methanol $(3: 7, \mathrm{v} / \mathrm{v})$ on ice for $30 \mathrm{~min}$. Homogenates were then extracted twice in $3 \mathrm{~mL}$ of distilled water, evaporated to dryness in a rotatory evaporator, and redissolved in $2 \mathrm{~mL}$ ultrapure $\mathrm{H}_{2} \mathrm{O}$. Amino acids were analyzed as $o$-phthalaldehyde derivatives on a reverse $\mathrm{C}_{18}$ column (Hypersil ODS, $3 \mu \mathrm{m}$, $250 \times 4.6 \mathrm{~mm})($ Knauer $\mathrm{GmbH}$, Berlin, Germany) using an automated HPLC system (Gerendás et al., 1998). Standards were prepared from authentic compounds, and norvaline was used as internal standard.

The ratio of tea polyphenol to amino acids can be used as a basis for determining tea quality.

Statistical analysis. Differences and correlation analysis between $\mathrm{N}$ fertilization and date, with regard to the growth, total $\mathrm{N}$ and $\mathrm{C}$, photosynthetic parameters, SPAD value, SOD, MDA, endogenous hormones, and inherent quality were tested by one-way analysis of variance using SPSS 16.0 statistical software (SPSS Inc., Chicago, IL). The reported data were the mean \pm SD of three biological replications.

\section{Results}

Plant growth and elemental concentrations. The level of $\mathrm{N}$ fertilization had a profound

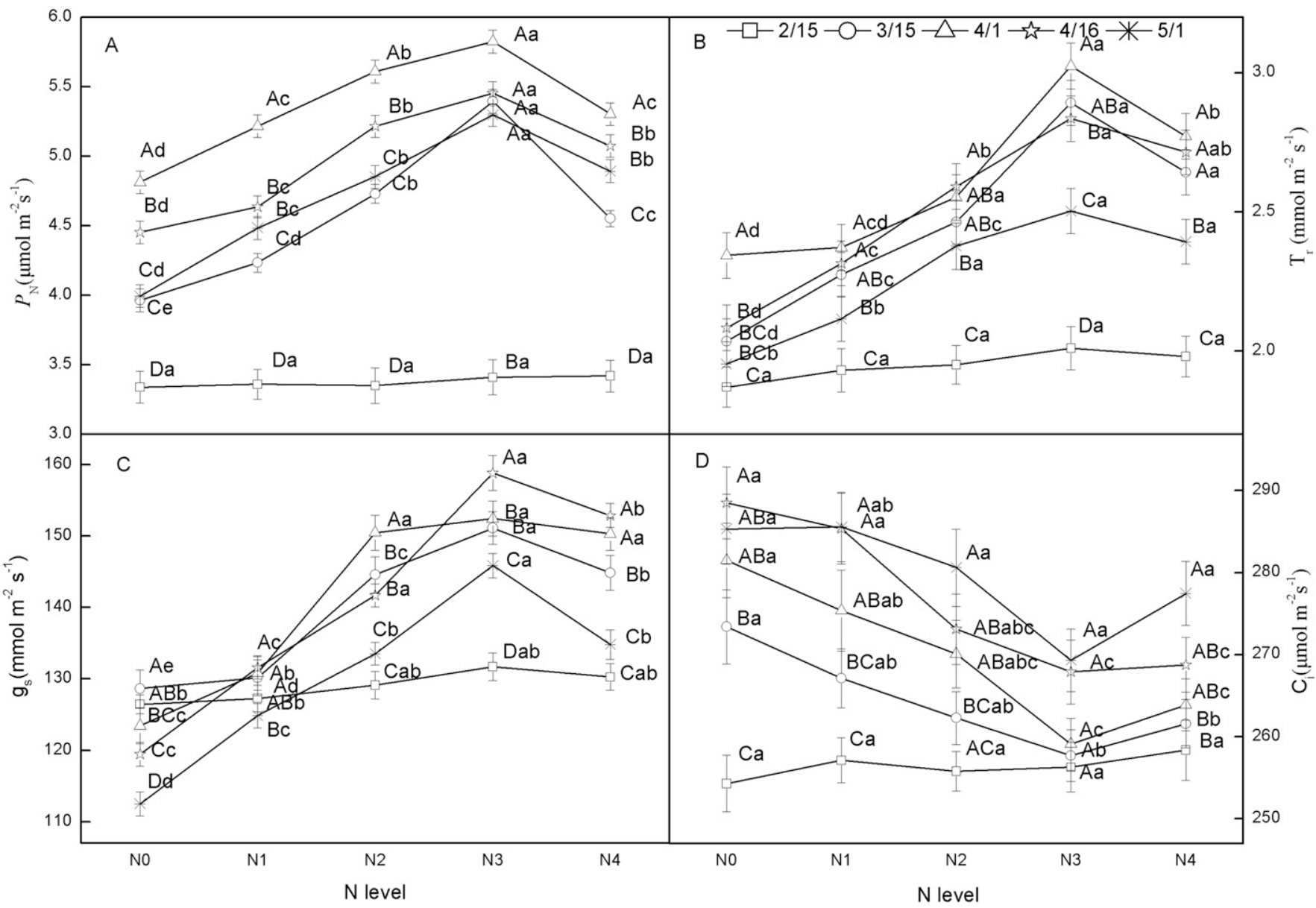

Fig. 2. Changes in leaf photosynthetic rate $\left(P_{\mathrm{N}}\right)(\mathbf{A})$, transpiration rate $\left(T_{\mathrm{r}}\right)(\mathbf{B})$, stomatal conductance $\left(g_{\mathrm{S}}\right)(\mathbf{C})$, and intercellular $\mathrm{CO}_{2}$ concentration $\left(C_{\mathrm{i}}\right)(\mathbf{D})$ in 'Wuniuzao' after $\mathrm{N}$ fertilization. Uppercase and lowercase letters indicate significance of $P<0.05$ by Duncan's test under the same $\mathrm{N}$ level and date, respectively. Error bars represent SD, $n=3$. N0, N1, N2, N3, and N4 refer to 0, 0.97, 1.94, 3.88, and 5.82 g/kg/pot N fertilization, respectively. 
effect on tea growth and mineral nutrition. The biomass of young shoots increased at first and then decreased by the increasing $\mathrm{N}$ level except for the start of $\mathrm{N}$ treatments, and it peaked under N3 (Table 1). Meanwhile, after 1 month of $\mathrm{N}$ treatments $(3 / 15)$, the young shoot biomass increased significantly compared with that on $2 / 15$. The changing trend of total $\mathrm{N}$ contents was consistent with that of young shoot biomass, which also increased to the maximum at N3, and there was a significant difference between N3 and N4 except for $2 / 15$ (Table 2). Compared with the start of $\mathrm{N}$ treatments $(2 / 15)$, there was a significant difference after 1 month of treatments. The changes in total $\mathrm{C}$ contents were the same as that of total $\mathrm{N}$, and we also found the immediate change after 1 month of $\mathrm{N}$ treatments (Table 3 ).

Chlorophyll (SPAD value). The chlorophyll contents in 'Wuniuzao' leaves after $\mathrm{N}$ treatments are shown in Fig. 1. The $\mathrm{N}$ levels affected SPAD values of 'Wuniuzao' leaves, and the SPAD values were higher than that of $\mathrm{N} 0$ after all $\mathrm{N}$ treatments. At the beginning of $\mathrm{N}$ treatments $(2 / 15)$, the SPAD value changed slowly with an increase in $\mathrm{N}$ level, and there was no significant difference with the increase in $\mathrm{N}$ level. After 1 month of growth, the SPAD value under all $\mathrm{N}$ treatments increased significantly compared with that of date $2 / 15$. The SPAD value under N3 reached the maximum with the increase in treatment dates.

Photosynthetic parameters. The $P_{\mathrm{N}}, T_{\mathrm{r}}$, $g_{\mathrm{S}}$, and $C_{\mathrm{i}}$ of tea leaves after $\mathrm{N}$ treatments were determined (Fig. 2). The $P_{\mathrm{N}}$ under different $\mathrm{N}$ levels was higher than that of N0. The $P_{\mathrm{N}}$ increased at first and then decreased with the increase in $\mathrm{N}$ level, it reached the maximum under $\mathrm{N} 3$, and there was a significant difference between N3 and other $\mathrm{N}$ treatments. After 1 month of $\mathrm{N}$ treatments, the $P_{\mathrm{N}}$ significantly increased compared with that of the beginning $\mathrm{N}$ treatments (Fig. 2A). The $T_{\mathrm{r}}$ under all $\mathrm{N}$ treatments increased with the increase in $\mathrm{N}$ level and it peaked under N3. There was a significant difference between date 2/15 and all other dates at the same $\mathrm{N}$ level (Fig. 2B). After $\mathrm{N}$ fertilization treatments, the $g_{\mathrm{S}}$ in tea leaves was significantly higher than that of N0 at the same date (Fig. 2C). At the end of $\mathrm{N}$ treatments, the maximum of $g_{\mathrm{S}}$ also appeared at N3; this was consistent with that of $P_{\mathrm{N}}$ and $T_{\mathrm{r}}$. The $C_{\mathrm{i}}$ of tea leaves significantly decreased after $\mathrm{N}$ fertilization treatments (Fig. 2D). Among the four $\mathrm{N}$ treatments, the $C_{\mathrm{i}}$ of $\mathrm{N} 3$ decreased the most compared with that of N0.

Antioxidant enzyme and MDA content. SOD activity of tea leaves gradually declined with the increase in $\mathrm{N}$ treatments time (Fig. 3A). The SOD activity was the highest under N3, and there was a significant difference between $\mathrm{N} 3$ and $\mathrm{N} 0$ at the same date (except for 2/15). Meanwhile, the SOD activity of all $\mathrm{N}$ treatments significantly declined compared with that of date $2 / 15$. The MDA content of tea leaves decreased significantly after $\mathrm{N}$ fertilization treatments, except for the beginning treatments (Fig. 3B). The MDA of N3 was the lowest among all the $\mathrm{N}$ treatments; at the end of $\mathrm{N}$ treatments $(5 / 1)$, it was $75.3 \%$ of N0. There was a significant change after 1 month of $\mathrm{N}$ treatments.
Endogenous hormones. The peak time of IAA, $\mathrm{GA}_{3}, \mathrm{ZT}$, and ABA for a standard sample is shown in Fig. 4. The peak time of

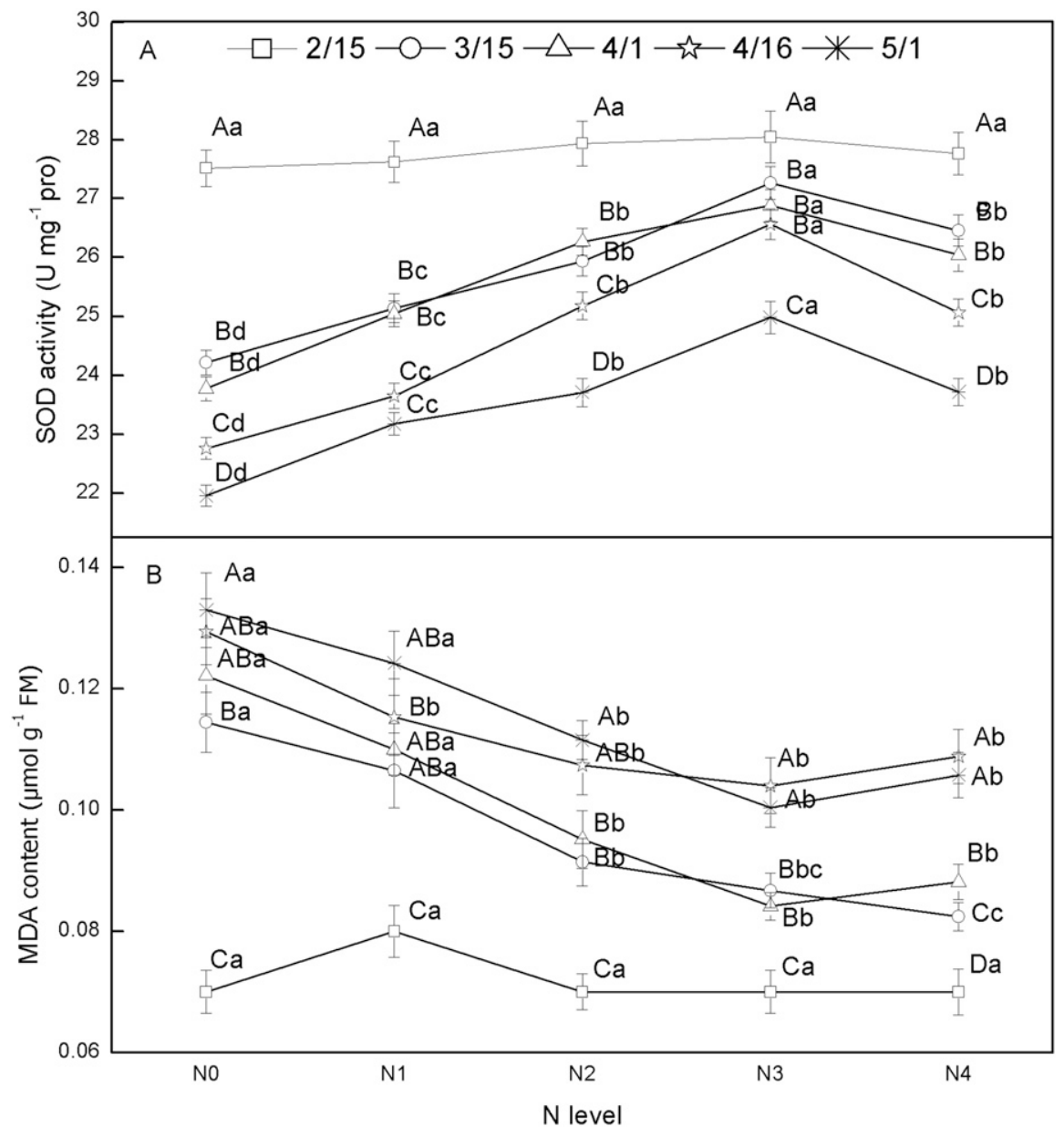

Fig. 3. Changes in leaf superoxide dismutase (SOD, A) and malondialdehyde (MDA, B) content in 'Wuniuzao' after nitrogen fertilization. Uppercase and lowercase letters indicate significance of $P<$ 0.05 by Duncan's test under the same $\mathrm{N}$ level and date, respectively. Error bars represent SD, $n=3$. N0, $\mathrm{N} 1, \mathrm{~N} 2, \mathrm{~N} 3$, and $\mathrm{N} 4$ refer to $0,0.97,1.94,3.88$, and $5.82 \mathrm{~g} / \mathrm{kg} /$ pot $\mathrm{N}$ fertilization, respectively.

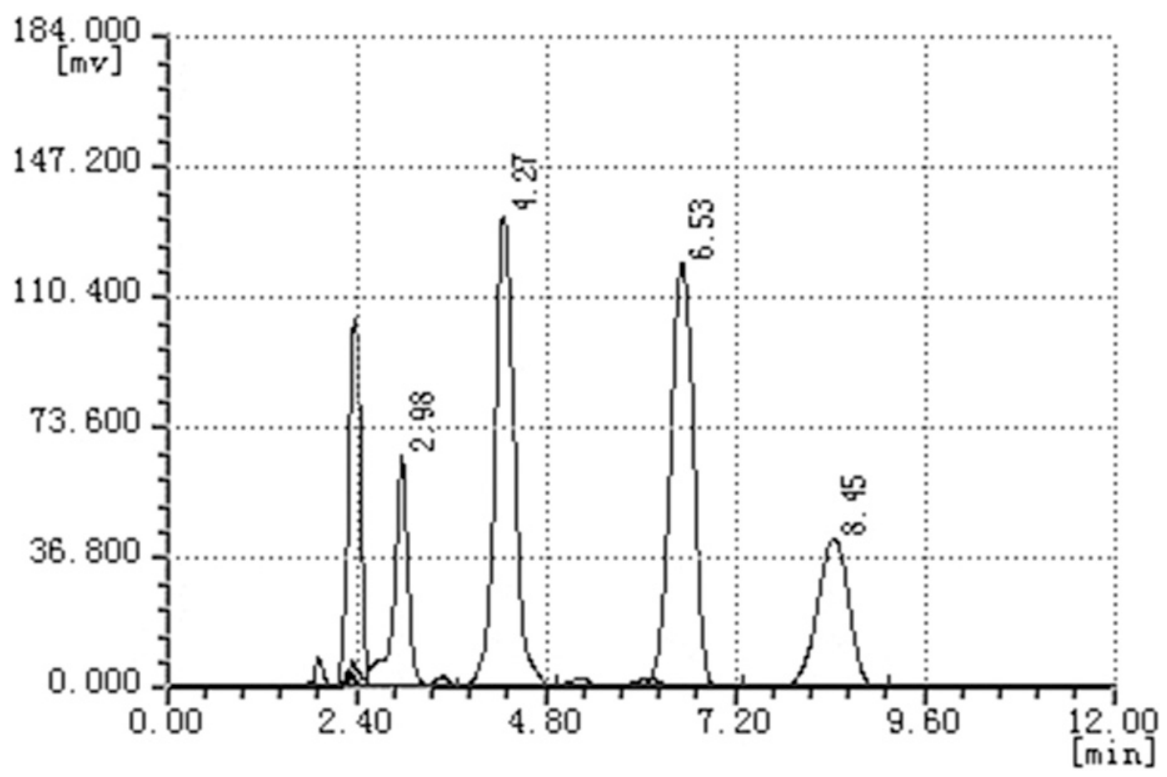

Fig. 4. The peak time diagram of indoleacetic acid, gibberellin, zeatin, and abscisic acid standard samples. 
ZT for the standard sample was $2.98 \mathrm{~min}$, $\mathrm{GA}_{3}$ was $4.27 \mathrm{~min}$, IAA was $6.53 \mathrm{~min}$, and ABA was 8.45. The recovery of ZT for the standard-spiked sample was $89.53 \%, \mathrm{GA}_{3}$ was $93.76 \%$, IAA was $101.45 \%$, and ABA was $110.88 \%$.

The changes in IAA, $\mathrm{GA}_{3}, \mathrm{ZT}$, and ABA in tea leaves were shown after $\mathrm{N}$ fertilization treatments (Fig. 5). The results showed that IAA could be significantly promoted by $\mathrm{N}$ fertilization from $\mathrm{N} 0$ to $\mathrm{N} 3$, and the IAA peaked under $\mathrm{N} 3$ among all treatments dates (Fig. 5A). After 1 month of $\mathrm{N}$ treatments, the IAA increased obviously. Except for N1 on $3 / 15, \mathrm{GA}_{3}$ contents in other $\mathrm{N}$ treatments were higher than that of N0. The highest $\mathrm{GA}_{3}$ content appeared in $\mathrm{N} 3$ during the whole treatment date (Fig. 5B). $\mathrm{N}$ fertilization treatments could also increase ZT contents of tea tender buds, with the maximum in N3; it indicated that $\mathrm{N} 3$ had a significant effect on the increase in $\mathrm{ZT}$ contents (Fig. 5C). One month later, ZT contents were significantly higher than that at the beginning of $\mathrm{N}$ treatments. The changes in ABA contents were contrary to those of IAA, $\mathrm{GA}_{3}$, and ZT; it declined at first and then increased, the minimums appeared under N3 (Fig. 5D). There was a significant difference after 1 month of $\mathrm{N}$ treatments (except for N4 at 5/1).

Inherent quality. The experiment showed that $\mathrm{N}$ fertilization increased caffeine contents (Fig. 6A). At the end of $\mathrm{N}$ treatments $(5 / 1)$, caffeine contents increased at first and then decreased with the increase in $\mathrm{N}$ level, and the peak appeared under N3. There was a significant difference between $\mathrm{N} 3$ and $\mathrm{N} 0$ under all $\mathrm{N}$ treatments, and caffeine contents significantly increased after 1 month of $\mathrm{N}$ treatments. $\mathrm{N}$ fertilization treatments decreased PP contents from N0 to N3, and PP was the lowest under N3 (Fig. 6B). The difference between the start of $\mathrm{N}$ treatments and 1 month was significant. The $\mathrm{N}$ fertilization treatments increased AA contents from $\mathrm{N} 0$ to N3; the highest value appeared in N3 (Fig. 6C). After 1 month of $\mathrm{N}$ treatments, AA contents changed significantly compared with those of the beginning (2/15). The changes in phenol ammonia were consistent with those of PP, decreased at first and then increased and the lowest value appeared at N3 (Fig. 6D). The less the phenol ammonia, the better the inherent quality.

Correlation analysis. Table 4 shows that there was a significant negative correlation between $\mathrm{PP}$ and $P_{\mathrm{N}}, \mathrm{SOD}$, and $\mathrm{ABA}$, and there was a significant positive correlation between PP and young shoot biomass, total $\mathrm{N}, \mathrm{SPAD}, C_{\mathrm{i}}$, MDA, and IAA. The correlation between AA and total N, total C, SPAD, $T_{\mathrm{r}}, g_{\mathrm{S}}$, IAA, $\mathrm{GA}_{3}$, and $\mathrm{ZT}$ was positive, whereas the AA and ABA negatively correlated. There was a significant positive correlation between caffeine and young shoot biomass, total $\mathrm{N}, \mathrm{SPAD}$ value, $T_{\mathrm{r}}, g_{\mathrm{S}}$, IAA, $\mathrm{GA}_{3}$, and $\mathrm{ZT}$; there was a significant negative correlation between caffeine and ABA. The phenol ammonia and $P_{\mathrm{N}}, g_{\mathrm{S}}, \mathrm{SOD}$, and ZT negatively correlated, whereas positively correlated with $C_{\mathrm{i}}$ and MDA. The results indicated that there was a close correlation between the inherent quality and young shoot biomass, total $\mathrm{N}$ and $\mathrm{C}$, photosynthesis, antioxidant enzyme activity, and endogenous hormones after $\mathrm{N}$ fertilization treatments. The changes in these parameters after $\mathrm{N}$ fertilization treatments improved the 'Wuniuzao' green tea quality.

\section{Discussion}

Photosynthesis is an important physiological process in plants, which can synthesize organic matter and generate energy (Caesar, 1989; Richardson et al., 2002). The

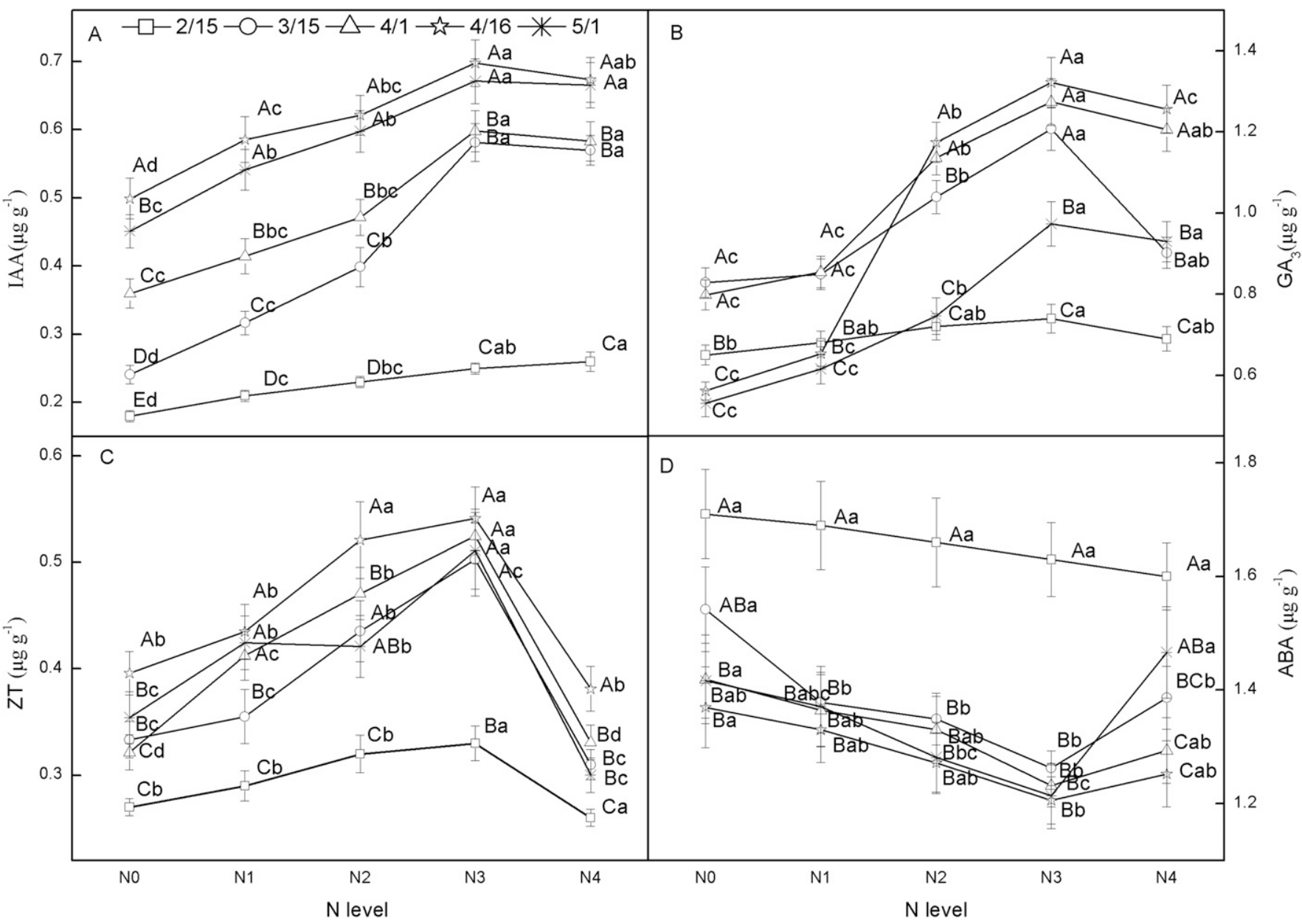

Fig. 5. Changes in leaf indoleacetic acid (IAA, A), gibberellin $\left(\mathrm{GA}_{3}, \mathbf{B}\right)$, zeatin (ZT, C), and abscisic acid (ABA, D) contents in 'Wuniuzao' after nitrogen fertilization. Uppercase and lowercase letters indicate significance of $P<0.05$ by Duncan's test under the same $\mathrm{N}$ level and date, respectively. Error bars represent SD, $n=3$. N0, N1, N2, N3, and N4 refer to $0,0.97,1.94,3.88$, and $5.82 \mathrm{~g} / \mathrm{kg} /$ pot N fertilization, respectively. 


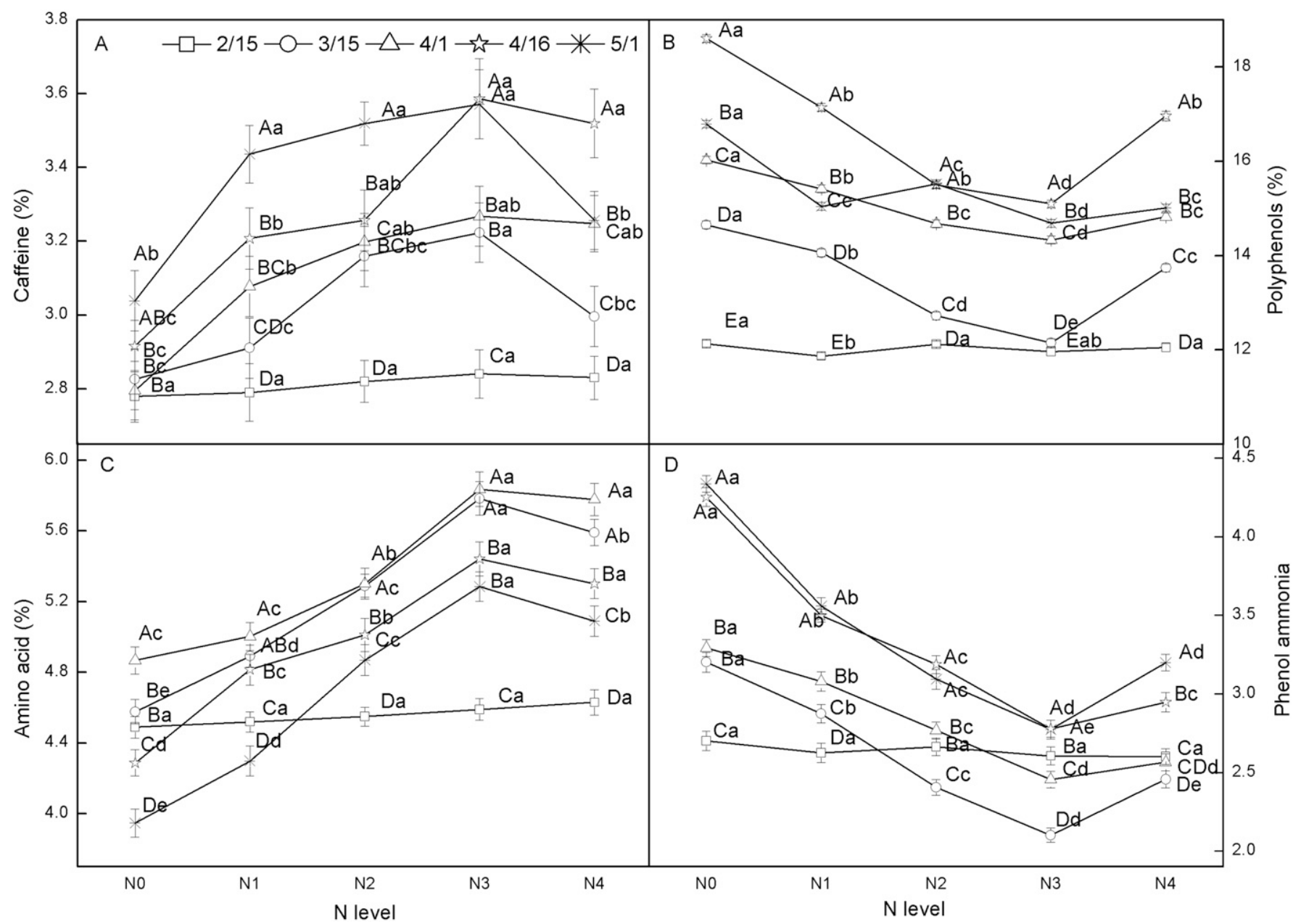

Fig. 6. Changes in leaf caffeine (A), tea polyphenols (B), amino acids (C), and phenol ammonia (D) in 'Wuniuzao' after nitrogen fertilization. Uppercase and lowercase letters indicate significance of $P<0.05$ by Duncan's test under the same N level and date, respectively. Error bars represent SD, $n=3$. N0, N1, N2, $\mathrm{N} 3$, and $\mathrm{N} 4$ refer to $0,0.97,1.94,3.88$, and $5.82 \mathrm{~g} / \mathrm{kg} /$ pot $\mathrm{N}$ fertilization, respectively.

Table 4. Correlation between inherent qualities and biomass, total $\mathrm{N}$ and $\mathrm{C}$, photosynthetic parameters, enzyme activities, and endogenous hormones of Wuniuzao.

\begin{tabular}{lcccc}
\hline Factors & PP & AA & Caffeine & Phenol ammonia \\
\hline Biomass & $0.518^{* *}$ & 0.275 & $0.826^{* *}$ & 0.224 \\
Total N & $0.505^{* *}$ & $0.482^{*}$ & $0.857^{* *}$ & 0.102 \\
Total C & 0.351 & $0.834^{* *}$ & 0.394 & 0.294 \\
SPAD value & $0.407^{*}$ & $0.626^{* *}$ & $0.828^{* *}$ & -0.038 \\
$P_{\mathrm{N}}$ & $-0.894^{* *}$ & 0.268 & -0.302 & $-0.835^{* *}$ \\
$T_{\mathrm{r}}$ & 0.174 & $0.925^{* *}$ & $0.637^{* *}$ & -0.387 \\
$g_{\mathrm{S}}$ & -0.128 & $0.911^{* *}$ & $0.608^{* * *}$ & $-0.628^{* *}$ \\
$C_{\mathrm{i}}$ & $0.871^{* *}$ & -0.371 & 0.240 & $0.867^{* *}$ \\
SOD & $-0.843^{* *}$ & 0.351 & -0.229 & $-0.847^{* *}$ \\
MDA & $0.879^{* *}$ & -0.266 & 0.274 & $0.819^{* *}$ \\
IAA & $0.551^{* *}$ & $0.559^{* *}$ & $0.815^{* *}$ & 0.105 \\
GA & 0.280 & $0.467^{*}$ & $0.691^{* *}$ & -0.040 \\
ZT & -0.031 & $0.881^{* *}$ & $0.516^{* *}$ & $-0.534^{* *}$ \\
ABA & $-0.554^{* *}$ & $-0.615^{* *}$ & $-0.804^{* *}$ & -0.081 \\
\hline
\end{tabular}

*Mean significantly correlated at 0.05 level; **mean significantly correlated at 0.01 level.

$P_{\mathrm{N}}$, net photosynthetic rate; $T_{\mathrm{r}}$, transpiration rate; $g_{\mathrm{S}}$, stomatal conductance; $C_{\mathrm{i}}$, intercellular $\mathrm{CO}_{2}$ concentration; SOD, superoxide dismutase; MDA, malondialdehyde; IAA, indole-3-acetic acid; $\mathrm{GA}_{3}$, gibberellin $\mathrm{A}_{3}$; ZT, zeatin; ABA, abscisic acid; PP, polyphenol; AA, amino acid.

chlorophyll content determines the intensity of photosynthesis; SPAD value is a dimensionless ratio value, and there was a positive correlation between SPAD value and chlorophyll content ( $\mathrm{Li}$ et al., 2006). The application of $\mathrm{N}$ fertilization increased SPAD value, $P_{\mathrm{N}}, T_{\mathrm{r}}$, and $g_{\mathrm{S}}$ of 'Wuniuzao' leaves, which were consistent with those of Haukioja (Haukioja et al., 1998), where N3 was superior to other treatments, indicating that increased $\mathrm{N}$ fertilization could improve the photosynthesis of tea tree. Increasing $\mathrm{N}$ level can increase the chlorophyll content in tea leaves. This may be due to two factors: $\mathrm{N}$ is an element of chlorophyll composition and $\mathrm{N}$ is an important element of enzymes, proteins, nucleic acids, and other macromolecules, which were related to chlorophyll synthesis in a plant. This was consistent with the results of $\mathrm{Gu}(\mathrm{Gu}$ et al., 2013). Nitrogen regulates plant photosynthesis by affecting leaf stomatal and nonstomatal factors. Nitrogen may regulate the opening and closing of stomata, and it is also an element of RuBP carboxylase composition, which comprehensively affects photosynthetic characteristics of leaves (Gao, 2013). N3 treatment is superior to N4 treatment; the excess $\mathrm{N}$ exceeds the tolerance of plants, for too high concentration of soil solution and plant water loss will result in "burn seedlings," and the excessive $\mathrm{N}$ fertilization will also cause resource waste and environmental pollution.

In addition to the degradation of chlorophyll and photosynthetic capacity, the imbalance of reactive oxygen metabolism is also a main characteristic of plant senescence. Some studies suggested that leaf senescence was due to the balance destruction between production and clearance of intracellular reactive oxygen and the accumulation of reactive oxygen caused cell damage (Jiang et al., 2007). This study showed that SOD 
activity in 'Wuniuzao' leaves significantly increased after $\mathrm{N}$ treatments, and SOD activity increased at first and then declined with the increase in N content. SOD is an important antioxidant enzyme in plants, and it can remove excessive reactive oxygen produced by internal stress; its activity level reflects the ability of plant resistance to senescence (Liu et al., 2007). MDA is a product of scavenging cellular reactive oxygen, and there is a positive correlation between MDA content and the peroxidation degree of the cell membrane. The results showed that MDA content of 'Wuniuzao' leaves decreased after $\mathrm{N}$ fertilization treatments, the MDA content increased at first and then decreased with the increase in $\mathrm{N}$ fertilization level. A possible reason is that physiological process of plants is the interaction of various organs and excess $\mathrm{N}$ will affect the balance of plant $\mathrm{C}$ and $\mathrm{N}$ metabolism, and it also inhibits the enzyme activity ( $\mathrm{Li}, 2012)$. The increase in SOD activity and decrease in MDA content showed that $\mathrm{N}$ fertilization could delay the senescence of 'Wuniuzao' leaves, and this result was consistent with that of Zhang and Wang (2010). It indicates that $\mathrm{N}$ fertilization can increase SOD activity and further enhance their capacity for scavenging reactive oxygen and, thus, delay the senescence of plants.

Plant hormones play an important role in cell division and elongation, differentiation of tissue, organ, flowering, seeding, ripening, senescence, dormancy, germination, plant morphological building, and in vitro tissue culture (Hung et al., 2008; Takei et al., 2001). This study showed that IAA, ZT, and $\mathrm{GA}_{3}$ contents of 'Wuniuzao' leaves after $\mathrm{N}$ treatments were higher, whereas ABA content was lower than that of CK. Nitrogen is an element of plant hormone composition and significantly affects the endogenous hormones of plants. The ZT, $\mathrm{GA}_{3}$, and IAA are growth-promoting hormones, $\mathrm{N}$ can promote their accumulation, and ABA is a growthinhibiting hormone, which starts and promotes plant senescence (Wang et al., 1994). This study showed that the contents of ZT and $\mathrm{GA}_{3}$ were the highest in $\mathrm{N} 3$, the content of $\mathrm{ABA}$ was the minimum, and the IAA content was the highest in N4. The reason may be that high auxin concentration inhibits growth, whereas low IAA concentration promotes growth. The effects of ABA on plant growth are relatively complex; it not only promotes senescence but also can regulate the switch of stoma and change in $T_{\mathrm{r}}$ (Yue et al., 2012). The tea polyphenol and amino acids are not only the metabolism materials but also are the main components that constitute tea quality, so that the phenol/ammonia ratio directly affects the quality of tea leaves (Deng et al., 2012).

This study suggested that $\mathrm{N}$ fertilization may improve contents of free amino acids and caffeine, and the conclusions were consistent with those of Yang (2011). This study confirmed that the content of tea polyphenol decreased with the increase in $\mathrm{N}$ fertilization level, the possible reason is that too much $\mathrm{N}$ makes most photosynthesis products to be used for protein synthesis, limiting the transformation from sugar to polyphenol (Zhao, 2007). Caffeine is the most abundant alkaloids in tea leaves, and it is an important taste substance (Yang, 2011). Nitrogen is a component of caffeine; previous studies showed that the caffeine content increased with the increase in $\mathrm{N}$ level, which is a result of the $\mathrm{N}$ nutrition situation being improved in tea tree.

\section{Conclusion}

In brief, we carried out this research in pot trials, and the results showed that the supply of $\mathrm{N}$ fertilization can affect the growth and quality of green tea in a short time. From the results, we can see that an optimal $\mathrm{N}$ level can promote growth and development, delay senescence, and improve the taste of green tea, which showed N3 (3.88 g/ $\mathrm{kg} /$ pot) was the appropriate $\mathrm{N}$ level for 'Wuniuzao' tea tree. We will conduct field trials in the future work.

\section{Literature Cited}

Astill, C., M.R. Birch, C. Dacombe, P.G. Humphrey, and P.T. Martin. 2001. Factors affecting the caffeine and polyphenol content of black and green tea infusions. J. Agr. Food Chem. 49:5340-5347.

Beauchamp, C. and I. Fridovich. 1973. Isozymes of superoxide dismutase from wheat germ. Biochim. Biophys. Acta 317:50-64.

Berges, J.A., D.O. Charlebois, D.C. Mauzerall, and P.G. Falkowski. 1996. Differential effects of nitrogen limitation on photosynthetic efficiency of photosystems I and II in microalgae. Plant Physiol. 110:689-696.

Bethke, P.C., I.G. Libourel, N. Aoyama, Y.Y. Chung, D.W. Still, and R. Jones. 2007. The Arabidopsis aleurone layer responds to nitric oxide, gibberellin, and abscisic acid and is sufficient and necessary for seed dormancy. Plant Physiol. 143:1173-1188.

Caesar, J. 1989. Effect of simulated shade radiation quality on the chlorophyll contents of long and short shoot early leaves of birch (betulapendula roth). Inst. Experimental Botany, Acad. Sci. Czech Republic NA Karlovce 1A, Prague 6, Czech Republic cs-16000.

Deng, M., Z. Xu, L.J. Hu, Y.H. Yao, M. Xu, and L. Pi. 2012. Effect of different levels of nitrogen application on yield and quality of Fuding Dabaicha. Southwest China J. Agr. Sci. 4:043.

Gao, P.J. 2013. Effects of nitrogen fertilization on photosynthetic capacity and spectral properties of phyllostachys pubescens. Beijing For. Univ., $\mathrm{PhD}$ Thesis.

Gerendás, J., Z. Zhu, and B. Sattelmacher. 1998. Influence of $\mathrm{N}$ and $\mathrm{Ni}$ supply on nitrogen metabolism and urease activity in rice (Oryza sativa L.). J. Expt. Bot. 49:1545-1554.

$\mathrm{Gu}$, Y., W.H. Hu, B.J. Xu, S.Y. Wang, and C.S. Wu. 2013. Effects of nitrogen on photosynthetic characteristics and enzyme activity of nitrogen metabolism in maize under-mulchdrip irrigation. Acta Ecologica Sinca. 33: 7399-7407.

Hanlon, E.A., J.G. Gonzalez, and J.M. Bartos. 1994. IFAS extension soil testing laboratory chemical procedure and training manual. Fla. Coop. Ext. Serv. Circ. 25, p. 812-816.

Haukioja, E., V. Ossipov, J. Koricheva, T. Honkanen, S. Larsson, and K. Lempa. 1998. Biosynthetic origin of carbon-based secondary compounds:
Cause of variable responses of woody plants to fertilization. Chemoecology 8:133-139.

Hung, K.T., D.G. Cheng, Y.T. Hu, and C.H. Kao 2008. Abscisic acid-induced hydrogen peroxide is required for anthocyanin accumulation in leaves of rice seedlings. J. Plant Physiol. 165:1280-1287.

Jiang, C., Y. Yin, X. Liu, and Z.L. Wang. 2007. Response of flag leaf lipid peroxidation and protective enzyme activity of wheat cultivars with different heat tolerance to high temperature stress after anthesis. Zuo Wu Xue Bao 33:143-148.

Kumar, S., A. Narula, and M.Z. Abdin. 2004 Enhancement in biomass and berberine concentration by neem cake and nitrogen (urea) and sulphur nutrients in Tinospora cordifolia Miers. Physiol. Mol. Biol. Plants. 10:243-251.

Li, W.J. 2012. Nitrogen physiology and its relation to leaf senescence of maize (Zeamays L.). Chinese Academy of Agr. Sci. PhD Thesis.

Li, Z.H., H.B. Lin, and Y.G. Zhang. 2006. A review on chlorophyll meter application on nitrogen fertilizer recommendation. Plant Nutr. Fert. Sci. 12:125-132.

Liu, W., K. Xu, H. Su, and H.L. Wang. 2007. Effect of nitrogen nutrition on physiological index of spinach senescence. Plant Nutr. Fert. Sci. 13:1110-1115.

Mudau, F.N., P. Soundy, E.S. du Toit, and J. Olivier. 2006. Variation in polyphenolic content of Athrixia phylicoides (L.) (bush tea) leaves with season and nitrogen application. S. Afr. J. Bot. 72:398-402.

Owour, P.O., C.O. Othieno, J.M. Robinson, and K. Baker. 1991. Response of tea quality parameters to time of year and nitrogen fertilizer. J. Sci. Food Agr. 55:111-446.

Owour, P.O., K.W. Ng'etich, and M. Obanda. 2000. Quality response of clonalblack tea to nitrogen fertilizer, plucking interval and plucking standard. J. Sci. Food Agr. 80:439-446.

Owour, P.O. and H.O. Odhiambo. 1994. Response of some black tea quality parameters to nitrogen fertilizer rates and plucking frequencies. $J$. Sci. Food Agr. 66:555-561.

Pan, G.S. and L.S. Qian. 2006. Endogenous hormones isplation and detection of tea. Chinese Tea Process. 1:44-46.

Richardson, A.D., S.P. Duigan, and G.P. Berlyn. 2002. An evaluation of noninvasive methods to estimate foliar chlorophyll content. New Phytol. 153:185-194.

Ruan, J.Y., X. Wu, Y.Z. Shi, and L.F. Ma. 2001. Nutrient input and evaluation of fertilization efficiency in typical tea areas of China. Soil Fert. 5:9-13.

Ruan, J., R. Haerdter, and J. Gerendás. 2010. Impact of nitrogen supply on carbon/nitrogen allocation: A case study on amino acids and catechins in green tea [Camellia sinensis (L.) O. Kuntze] plants. Plant Biol. 12:724-734.

Rufty, T.W., S.C. Huber, and R.J. Volk. 1988 Alterations in leaf carbohydrate metabolism in response to nitrogen stress. Plant Physiol. 88:725-730.

Su, Y.J., W.Y. Liao, Y. Ding, H.C. Wang, and X.J. Xia. 2011. Effects of nitrogen fertilizer on yield and quality of tea. Plant Nutr. Fert. Sci. 17:1430-1436.

Takei, K., H. Sakakibara, M. Taniguchi, and T. Sugiyama. 2001. Nitrogen-dependent accumulation of cytokinins in root and the translocation to leaf: Implication of cytokinin species that induces gene expression of maize response regulator. Plant Cell Physiol. 42:85-93.

Wang, Y.Y., R. Zhou, and X. Zhou. 1994. Endogenous levels of ABA and cytokinins and their relation to stomatal behavior in dayflower 
(Commelina communis L.). J. Plant Physiol. 144:45-48.

Wanyoko, J.K. 1983. Fertilizer on tea: Nitrogena review. Tea 4:28-35.

Yang, Y.Y. 2011. Quality-related constituents in tea leaves as affected by nitrogen. Nanjing Agr. Univ., PhD Thesis.

Yang, Y.Y., L.F. Ma, Y.Z. Shi, J.Y. Chen, and X.H. Li. 2008. Evaluation of nitrogen status in tea plants by SPAD. Tea Sci. 28(4):301-308.

Yue, C., J.M. Zeng, Z.F. Zhang, X.C. Wang, and H.L. Cao. 2012. Research progress in the phytohormone of tea plant (Camellia sinensis). J. Tea Sci. 32:382-392.

Zhang, S.J., Y.J. Huang, Q.C. Ren, X.Q. Zhang, Z.X. Yang, and T.Z. Yang. 2010. Effects of nitrogen fertilizer on leaf senescence, photosynthetic characteristics, yield, and quanlity of different flue-cured tobacco varieties. Chinese J. Applied Ecology 21:668-674.

Zhang, Y.C. and L.C. Wang. 2010. Effect of low temperature stress on membrane permeability and protection of activity in tea leaves. Northern Horticulture 9:38-40.
Zhao, W.J., C.C. Xu, and Q. Zou. 1994. Improvements of method for measurement of malondialdehyde in plant tissues. Plant Physiol. Commun. 30:207-210.

Zhao, W.X. 2007. Effect of nitrogen fertilizer on yield and quality of tea and ecological fitness of Toxoptera aurantii boyer. Fujian Agr. For. Univ., PhD Thesis.

Zhou, X.J., Y. Liang, H. Chen, S.H. Shen, and Y.X. Jing. 2006. Effects of rhizobia inoculation and nitrogen fertilization on photosynthetic physiology of soybean. Photosynthetica 44:530-535. 